\title{
Prostate imaging and focal therapy
}

This special edition of Translational Andrology and Urology (TAU) has a focus on Prostate Imaging and Focal Therapy. It is published at the end of a decade of immense change in our understanding of the tumour biology, genomics, optimal diagnosis and treatment of localised prostate cancer.

The heterogeneity of prostate cancer has presented a challenge to researchers in identifying a responsible cardinal genomic alteration. In the opening article Dr. Hayley Whitaker provides a summary of the state-of-art pertaining to tumour biology and genomics from diagnosis to metastatic disease.

Recent diagnostic highlights have been the validation of pre-biopsy multi-parametric MRI (mp-MRI) and MRI-targeted biopsy strategies over a systematic transrectal ultrasound guided-biopsy (TRUS-GB) approach. In this respect, Prof. Leonard Marks, Prof. Tilman Loch and Prof. Jochen Walz succinctly cover the role of systematic sampling in an MRI-targeted prostate biopsy strategy, the role of prostate ultrasound in an MRI-era and the current available techniques in prostate biopsy sampling, respectively.

Treatment strategies have also broadened, with the development of minimally-invasive therapies that can focally treat an area of the prostate in which a cancer resides. In part, driven by the emergence of the index-lesion theory, which suggests that in most men that a one or two lesions are biologically and clinically aggressive and drive metastatic potential. An update on the evidence base for tissue preservation, lesion-directed therapy and the available treatment modalities is provided by Prof. Hashim Ahmed.

Further, the favorable toxicity profile of focal therapy, when compared to whole-gland treatment, has led to a rising adoption amongst both urologists and patients. Dr. Tim Dudderidge explores whether there is enough evidence to now routinely consider focal therapy alongside whole-gland treatment options at the multi-disciplinary team meeting (MDT) or tumour board. In cases of whole-gland treatment failure focal therapy may offer a salvage approach and in our final article, Dr. Taimur Shah shares the accumulating evidence base for salvage focal therapy in men with evidence of radio-recurrent disease.

\section{Acknowledgments}

We would like to thank the following international senior authors in this focused issue for their valuable contributions: Professor. Leonard S. Marks (Department of Urology, David Geffen School of Medicine at University of California Los Angeles, California, USA); Professor. Tillman Loch (Klinik und Poliklinikfiir Urologie und Kinderurologie der Universitdt des Saarlandes, Homburg, Germany); Professor. Jochen Walz (Department of Urology, Institut Paoli-Calmettes Cancer Centre, Marseille, France); Professor. Hashim U. Ahmed (Imperial Prostate, Department of Surgery and Cancer, Imperial College London, Charing Cross Hospital, London, UK); Dr. Tim Dudderidge (Department of Urology, University Hospital Southampton, Southampton, Hampshire, UK); Dr. Hayley Whitaker (Division of Surgical and Interventional Sciences, Faculty of Medicine, University College London, London, UK); Dr. Taimur T. Shah (Imperial Prostate, Department of Surgery and Cancer, Imperial College London, Charing Cross Hospital, London, UK).

Funding: None.

\section{Footnote}

Provenance and peer review: This article was commissioned by the editorial office, Translational Andrology and Urology for the series "Prostate Imaging and Focal Therapy". The article did not undergo external peer review.

Conflicts of Interest: All authors have completed the ICMJE uniform disclosure form (available at http://dx.doi.org/10.21037/ tau.2020.02.27). The series "Prostate Imaging and Focal Therapy" was commissioned by the editorial office without any funding or sponsorship. Martin J. Connor has received funding from the Wellcome Trust and University College London Hospital Charity (UCLH). Hashim U. Ahmed reports receipt of grant funding and personal fees from SonaCare Medical Inc., grant funding from Trod Medical, and grant funding and personal fees from Sophiris Bio Inc. and Boston Scientific. 
HUA also receives core funding from the UK National Institute of Health Research Imperial Biomedical Research Centre and grants from Wellcome Trust, MRC (UK), Cancer Research UK, Prostate Cancer UK, The Urology Foundation, BMA Foundation, Imperial Healthcare Charity and the NIHR Imperial BRC. MJC, SM, TTS and HUA served as the unpaid Guest Editors of the series.

Ethical Statement: The authors are accountable for all aspects of the work in ensuring that questions related to the accuracy or integrity of any part of the work are appropriately investigated and resolved.

Open Access Statement: This is an Open Access article distributed in accordance with the Creative Commons AttributionNonCommercial-NoDerivs 4.0 International License (CC BY-NC-ND 4.0), which permits the non-commercial replication and distribution of the article with the strict proviso that no changes or edits are made and the original work is properly cited (including links to both the formal publication through the relevant DOI and the license). See: https://creativecommons.org/ licenses/by-nc-nd/4.0/.

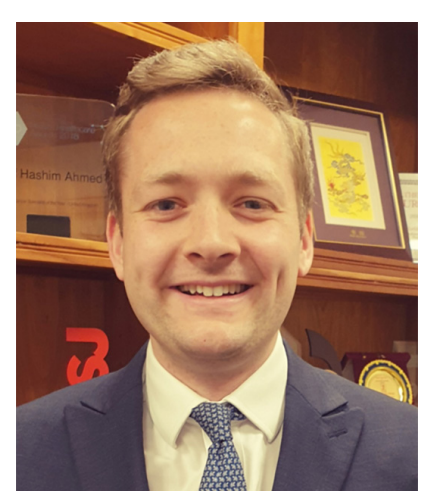

Mr. Martin J. Connor, BSc (Hons), MBBS, MSc, MRCS

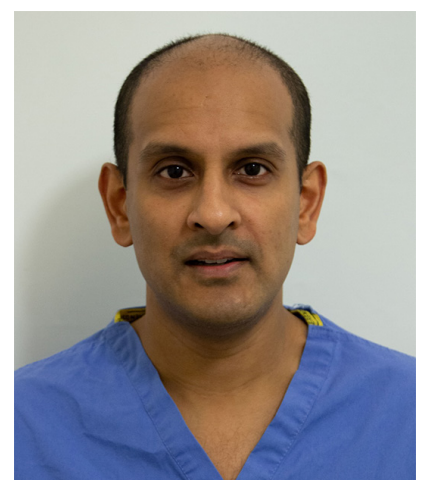

Mr. Saiful Miah, BSc (Hons), MB ChB, PhD, FRCS (Urol)

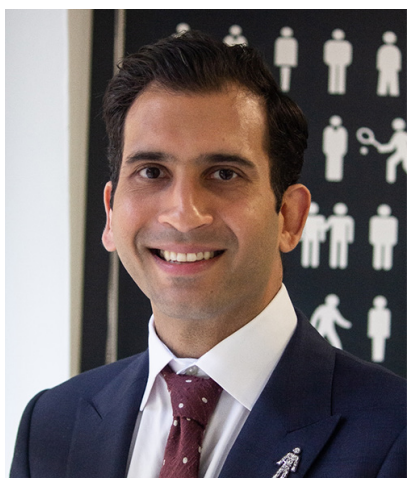

Mr. Taimur T. Shah, BSc (Hons), MBBS, FRCS (Urol)

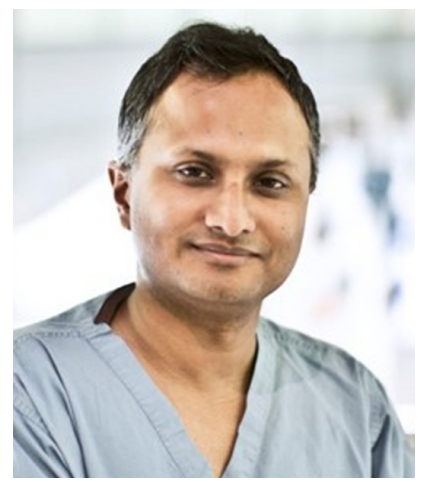

Professor. Hashim U. Ahmed, BA (Hons), BCh (Oxon), BM, PhD, FRCS (Urol)

\section{Martin J. Connor ${ }^{1,2}$ \\ (Email: m.connor@imperial.ac.uk) Saiful Miah ${ }^{1,3}$ \\ (Email: saiful.miab@nbs.net) \\ Taimur T. Shah ${ }^{1}$ \\ (Email:t.shab@imperial.ac.uk)}

Hashim U. Ahmed ${ }^{1,2}$

(Email: bashim.abmed@imperial.ac.uk)

${ }^{1}$ Imperial Prostate, Department of Surgery and Cancer, Imperial College London, Charing Cross Hospital, London, W6 8RF, UK;

${ }^{2}$ Department of Urology, Imperial College Healthcare NHS Trust, Charing Cross Hospital, London, W6 8RF, UK;

${ }^{3}$ Department of Urology, Addenbrooke's Hospital, Cambridge University Hospital NHS Foundation Trust, CB2 0QQ, UK

Submitted Feb 11, 2020. Accepted for publication Feb 24, 2020.

doi: $10.21037 /$ tau.2020.02.27

View this article at: http://dx.doi.org/10.21037/tau.2020.02.27

Cite this article as: Connor MJ, Miah S, Shah TT, Ahmed HU. Prostate imaging and focal therapy. Transl Androl Urol 2020;9(3):1479-1480. doi:10.21037/tau.2020.02.27 